\title{
INDO-PAK RELATIONS AND THE KASHMIR PROBLEM: FROM 1947 TO THE PRESENT DAY
}

India and Pakistan, the two dominant forces from southern Asia have always had problematic relations over Kashmir ever since the two countries came into existence in 1947 . The conflict in Kashmir has been going on for decades, the nature of which has changed with the passage of time. One really doesn't know what the future is for the people of Kashmir. It is proving to be one of the longest conflicts and is often compared with the Arab Israeli conflict. It is the aim of this paper to look into the background of the conflict and to give readers an overview of Indo-Pak relations, and to see how the conflict has changed its character with the passage of time.

\section{METHODS USED FOR THIS PAPER:}

The paper is especially interested in the voices of ordinary people, and takes a bottom -up approach. The paper makes a shift from the traditional top-down approach when scholars in the past have had a tendency to interview the political elite for their research. The arguments put forward by the people are often not in keeping with the stories, and arguments put forward by the political elite. The bottom-up approach was carried out by doing semi-structured or what is also called non-directive interviews with the people of Kashmir. 'The least structured form of interviewing is the non-structured or non-directive interview. Here no pre-specified set of questions are employed, nor are the questions asked in a specified order' (Nachmias, 1992, 225). There is no schedule. 'With little or no direction from the interviewer, respondents are encouraged to relate their experiences, to describe whatever events seem significant to them, to provide their own definitions of their situations, and to reveal their opinions and attitudes as they see fit. The interviewer has a great deal of freedom to probe various areas and to raise specific queries during the course of the interview' (Ibid). 'Interview methods can be based on narrations and story-telling done by the interviewee in order to minimise structuring on the part of the interviewer' (Scheibelhofer, 2008, 405). This flexibility and the spontaneity with which the interviewees respond are most certainly some of the strengths of this method. Data gathered through interviews allows us as researchers to locate the biography of the individual who is being interviewed in the broader cultural domains in which they live, and thus we should be able to connect their personal story to the broader context (Forsey, 2010, 568-569). This approach has been taken in this paper.

In addition to semi structured interviewing, participant observation was also used as another method for purposes of this paper. Participant observation is 'a research strategy in which the observer's presence in a social situation is maintained for the purpose of scientific investigation'(Burnham, 2004, 222). It has been 'defined as a process in which an investigator establishes a many sided and relatively long term relationship with a human association in its natural setting for the purpose of developing a scientific understanding of that association' (Ibid). Thus, a few trips were taken to Kashmir over the past few years, and data was gathered partly by spending time there, through participant observation.

\section{THE THEORETICAL BACKGROUND FOR CONFLICTS IN SOUTH ASIA:}

When we look at the origins of conflicts in the subcontinent, well known scholar on South Asian affairs, Professor Sumit Ganguly, rightly points out that there are four to five main sources from which these contemporary conflicts arise (Ganguly in Brown,1996, 141-172). The first category of conflicts according to Professor Ganguly is strongly tied up with the British colonial legacy. The 
British colonial administrators in the subcontinent wanted to avoid a united resistance from the two main religious communities i.e. the Hindus and the Muslims, and hence they followed a policy of divide and rule. These two religious communities were kept divided so that the colonial authorities would not have to face a united resistance. Hindus and Muslims have lived next to each other for centuries. The story is one of conflict as well as collaboration and friendship, but the colonial authorities chose to focus on the differences to deliberately worsen the existing cleavages. A united India was always seen as a threat to the British colonial administration. Any Hindu-Muslim tension in contemporary India, including the Kashmir conflict can be traced back to these times.

The second group of conflicts, according to Professor Ganguly are the conflicts which arise as a result of the process of modernisation and globalisation. The process of modernisation opens up doors, opportunities and possibilities for some, but it leaves others feeling marginalised and excluded, and hence when the two sides clash, a conflict is born. Furthermore, the process of modernisation has had an eroding impact on existing norms, tears the bonds which exist between communities and also sharpens class differences. The present day Maoist insurgency in central and eastern India is a good example of a conflict that falls into this category. Religious fundamentalist movements also fit into this category (Armstrong, 2000/1, 140). For instance, Karen Armstrong argues, 'a fundamentalist movement does not arise immediately as a knee jerk response to the advent of western modernity, but only takes shape when the modernisation process is quite far advanced. At first religious people try to reform their traditions and effect a marriage between them and modern culture, but when these moderate measures are found to be of no avail, some people resort to more extreme methods, and a fundamentalist movement is born' (Ibid).

The third group of conflicts happen as a result of the struggle for limited resources in a particular region. Given that there are limited resources, ethnic mobilization can often lead to outbreaks of violence. The conflicts in the eastern part of the subcontinent e.g. the Indian northeast fit into this category.

A large number of conflicts have come into existence as a result of external intervention in South Asia. For example, the Soviet invasion of Afghanistan in 1979 left the country absolutely devastated. This decade long invasion allowed different groups in the Af-Pak region (Afghanistan/Pakistan taken collectively) such as warlords and Islamists to have easy access to weapons. And this easy availability of weapons in the Af-Pak region has now paved the way for a new set of conflicts to come into existence in the post-Cold War phase. The American security establishment, through General Zia in Pakistan, supported the Afghan mujahideen in their war against the Soviets during the Cold War, and supplied them with weapons and training. Sita Bali argues, 'It was Pakistan that co-ordinated help to the mujahideen to reverse the Soviet invasion'(Bali in Dutt, 2012, 38). Furthermore, when the invasion took place, hundreds of Afghans fled to neighbouring Pakistan for shelter and came into conflict with the original inhabitants of Pakistan. So a new range of ethnic conflicts have come into existence in the Af-Pak region as a result of this migration. This has also happened after 9/11, with the onset of American bombing of the Af-Pak region. Although the Durand Line, (named after Sir Mortimer Durand) separates the Afghan Pushtun tribes from the Pakistani Pushtun tribes, the Afghan's refuse to recognise this demarcating line (Rashid, 2008). 'The porous border traffic on the Pakistan Afghanistan border consists not only of Pashtuns exercising easement rights granted to them decades ago across the Durand Line but also internally displaced persons fleeing violence on both sides of the border' (Beg in Durward, 2009, 
150). Thus, during times of invasion of Afghan territory, firstly by the Soviets and more recently by the Americans, many Afghans have crossed over into neighbouring Pakistan for shelter (Steele, 2011, 233). And although this provides the fleeing Afghans with some temporary relief, we see with the passage of time, they tend to come into conflict with the existing residents of Pakistan, paving the way for new inter-ethnic tensions.

It has also been argued that ethno religious discord and violence in South Asia has worsened to some extent as a result of India's flourishing democracy. Increased access to education, the growing exposure of the media, the rise of grass roots power through local and state elections have all contributed to an awareness amongst previously marginalised groups, who have now become increasingly assertive in Indian politics. And as they make their presence felt, there is resistance from the political elite, who want to hold onto the status quo.

These categorisations made by Professor Ganguly are indeed very useful and give us some understanding into the theoretical background of conflicts in contemporary South Asia. Now let us take a closer look at the situation in Kashmir.

\section{THE HISTORY OF INDO-PAK RELATIONS AND THE KASHMIR CONFLICT:}

Geographically, Kashmir is located at the intersecting point between South Asia and Central Asia, and is India's northern most state, often seen as the starting point of the great Himalayan mountain range. This is a disputed territory between India and Pakistan. 'The history of Kashmir over the past fifty years is the history of two territories with different patterns of development, but the populations of both areas continuing to dispute the division' (Ellis and Khan in Talbot and Singh, 1999, 270). The division of Kashmir was not accepted by many of its population and thus still continues to be the subject of dispute (Ibid). In 1947, when the British withdrew from South Asia, the rulers of the independent princely states, of which Kashmir was one, had the choice of acceding either to India or to Pakistan. 'With the departure of the British from the Indian subcontinent in August 1947, all Indian princes were faced with a momentous decision: to join their domains with either India or Pakistan' (Snedden, 2013, 8). Independence wasn't really a choice since it would have led to the fragmentation of the subcontinent. According to the British plan, the monarchy could choose to which state it would be a part of. Kashmir like Hyderabad in the south posed a peculiar problem: they had Hindu populations with Muslim monarchs or Muslim populations with Hindu monarchs (Brown, 1996, 149).In Kashmir, Maharaja Hari Singh, who was from a Hindu background, ruled over a predominantly Muslim population. Shashi Tharoor writes, 'The Maharaja of Jammu and Kashmir-a Muslim majority state with a Hindu ruler-dithered over which of the two to join, and flirted optimistically with the idea of remaining independent' (Tharoor, 2012/13, 27). In the weeks before independence most Indian princely states gave into Indian pressure. But, 'it caused explosive situations and armed resistance in the princely states of Kashmir and Hyderabad, where national allegiances were not clear cut and were complicated by diverse populations' (Khan, 2007, 98).

The leader of the Pakistan movement and the founding father of modern Pakistan, Mohammed Ali Jinnah tried his best to win support of the Kashmiri people, so that Kashmir would accede to the Pakistani side. Yet, there was hardly much support for Jinnah in Kashmir. Kashmir can be easily divided into three major spheres of influence: Azad Kashmir, which is mainly Muslim, Jammu, which has a mixture of both Hindus and Muslims, and Aksai Chin, which is associated with the Buddhists from Ladakh (Habibullah, 2011,7). The part of Kashmir which tilts towards the 
predominantly Muslim Pakistani side can be seen as the Pakistani sphere of influence, the southern bit, often called Jammu and Kashmir, which is closer to the Indian side can be seen as the Indian sphere of influence, and the extreme north eastern part of Kashmir tilting towards Tibet/China, can be viewed as the Chinese sphere of influence. Many from the Buddhist and Hindu communities did not want to be a part of Pakistan because they perceived Muslim rule as oppressive. For instance, in 1949, 'the Buddhist Association of Ladakh had sent a memorandum to Nehru (the then Indian leader) suggesting that Ladakh be integrated with Jammu in some way, either to become an Indian state in its own right or as part of east Punjab totally separate from Sheikh Abdullah's administration in Kashmir' (Schofield, 2010, 81). The people from Ladakh, who were of Tibetan origin, soon came to realise that Sheikh Abdullah had little knowledge of their way of life (Ibid). Furthermore, there were also Muslim peasants who wanted to be a part of India, since they thought they would have a brighter economic future in India as opposed to Pakistan.

Because of the peculiar situation Kashmir was in, Maharaja (king of kings) Hari Singh could not make up his mind which side to join: the Indian side or to the Pakistani side. 'Kashmir had a Muslim majority but a Hindu Maharaja who dragged his feet when he was expected to accede to one dominion or the other' (Kulke and Rothermund, 1986, 292). In 1947, a rebellion broke out in a place called Poonch, which is located in the south western part of Kashmir, sandwiched in between India and Pakistan. When the rebellion took place, the Pakistani security establishment sent in their army to assist the rebels to overthrow the rule of the then Hindu monarch. Much of the Pakistani army were disguised as local tribesmen. Pakistan also made use of the services of the Pashtuns in this connection. 'Pashtun fighters were deployed in the battle for control of Muslim Kashmir after the Hindu Maharaja Sir Hari Singh declared Kashmir's accession to India in 1947' (Siddique, 2014, 37). The Pakistani government relied on Pashtun armed groups from both sides of the Durand Line to fight as its 'surrogate army' (Ibid). Pakistan tried to force Kashmir to accede to Pakistan, but as the situation worsened, Hari Singh turned to the Indian side for assistance (Schofield, 2010, 52). Nehru, the then leader from India, and India's first prime minister, agreed to help Hari Singh, on the grounds that he would have to accede to India. The emergency situation and situation of political turmoil did not give Hari Singh much choice, and hence at the time he agreed. It is very interesting though that he turned to the Indian side for assistance and not to the Pakistani side. Because of his own Hindu background, it is possible, that he felt a sense of oneness and identification with India, a country which has a Hindu majority. Because of the on-going turmoil and political crises, a referendum at that time was also not possible. Hence, a document called the 'Instrument of Accession' was signed between the two parties. Maharaja Hari Singh acceded 222, 236 kilometres of territory by way of the Instrument of Accession to the Domain of India (Razdan in Sinha, 2012, 226). Finally, Indian troops arrived in Kashmir to save the situation. At this stage, the UN intervened. However, despite UN intervention, there was a political deadlock. The Pakistani side argued for a plebiscite, but the Indian side argued for a plebiscite on the grounds that Pakistan removed its men particularly from the Poonch area (Schofield, 2010, 70-72).

When Kashmir agreed to accede to India, the basic issue revolved around Kashmir's autonomy within mainstream India, and that it would have a special status unlike the other British Indian states. According to the agreement between India and Kashmir, the Indian government would have control and authority over Kashmir in three areas which included defence, communications and external relations (Bajpai, 2002, 45). All other issues were to be dealt with by the Kashmir government. In the year, 1950, Kashmir was given special status according to article 370 of the 
constitution of India. The Kashmir flag was also supposed to fly alongside the Indian flag. The 'sadr-iriyasat', or governor of Kashmir was to be elected by the state legislature, unlike all the other states where he was to be appointed by the president. The central government could make laws in other areas as well if it thought this was necessary, such as proclaiming an emergency, but only with the agreement of the Kashmir regional government (Ibid). The central government from New Delhi, however, in different ways gradually started to extend its full authority over the Kashmir region. The political establishment at New Delhi was mainly concerned with the recalcitrant behaviour of the National Conference Party, and its leader, Sheikh Abdullah. Abdullah was increasingly proving to be a thorn to the Indian establishment when the Indian establishment was trying to integrate Kashmir into India proper. Abdullah had been arrested on a few occasions, and his government had been dismissed. With the passage of time, we see the erosion of Kashmir's special status and India trying to force Kashmir into accepting Indian authority. For instance, between, 1957-1966, the Kashmir constitution was amended to convert the 'sadr-i-riyasat', into a governor, and the prime minister into chief minister, making it similar to all the other Indian states in the Indian union. For Kashmiri's, these were signs of the gradual subversion of its autonomy and special status.

One reason why, the Kashmir conflict is so complex is because the conflict has both an internal side as well as an external dimension to it (Mukherjee, 2014). The internal side relates to India's repressive/draconian measures in the region to suppress the recalcitrant separatist groups (Mukherjee, 2014), and the external side relates to Pakistan's involvement in the conflict, and the four Indo-Pak wars. For politicians at New Delhi, borderland conflict zones are always viewed with fear since it is very difficult to make an assessment of the involvement of external forces in these peripheral conflict zones. Pakistan's 'Kashmir strategy reflected the long standing Pakistani strategy of promoting Kashmiri accession to Pakistan, and not Kashmiri independence' (Lieven, 2012, 189).

India had suffered a crushing defeat in the hands of neighbouring China in 1962, and the military establishment in Islamabad thought that at this juncture, India was weak from a military standpoint. Thus, there was a 'now or never' approach taken by Pakistan in the mid-sixties, which is when the second Kashmir War took place. Pakistan's strategy at this point in time was called Operation Gibraltar. Anti-Indian riots in the Kashmir valley convinced the Pakistani leadership that there was widespread and popular support for Pakistan's rule in Kashmir. 'Operation Gibraltar was conceived largely by civilians and a small group of decision makers who included Foreign Minister Zulfikar Ali Bhutto, Foreign Secretary Aziz Ahmed, and the commanding officer for the Kashmir area, General Akhtar Malik...The plan consisted of sending 7000 to 8000 specially trained mujahid soldiers into Indian Kashmir to dislocate and disorganise the Indian Army by sabotaging Indian military installations and communication facilities' (Paul, 2014, 48). Pakistan also viewed India's political moves to integrate Kashmir within India proper, with suspicion. In his broadcast, General Ayub Khan warned the people of Pakistan, that India's aggression in Kashmir was only a preparation for an attack on Pakistan (Hiro, 2011, 167). Although Kashmir was supposed to have special status, there was no sign of it, and it increasingly started to resemble all the other Indian states. 'During much of 1962/63, Zulfikar Ali Bhutto was engaged in lengthy negotiations with his Indian counterpart, Swaran Singh, to persuade India to recognise Kashmir's special status as a disputed territory' (Shaikh in Guha, 2014, 280). Pakistan's plan to free Kashmir from Indian rule ultimately failed. Finally, UN involvement brought the war between India and Pakistan to a temporary close in the year 1965 . The former Soviet Union mediated a settlement in Tashkent in the year 1966, and the situation remained dormant for a while. 
Whilst externally, Pakistan was waging war with India to capture Kashmir, internally a lot was also going on. For instance, in 1968, Sheikh Abdullah organised the All Kashmir States People's Convention which had the aim of trying to gain more autonomy for Kashmir from India. New Delhi was suspicious of the National Conference and tried to control it by forming an alliance with it and this paved the way for the Conference-Congress alliance, which won the elections in 1987. However, there was a lot of bloodshed in the violence that broke out shortly afterwards because it was felt that the elections had been rigged and that they had not been carried out in a fair and just way. lan Talbot writes, 'Kashmiri Muslims' alienation from the Indian state intensified after the blatant rigging of the June 1987 state elections' (Talbot, 2000, 276). This led to massive protests, and the Indian government responded to these protests with a wave of repression which included arrests, detentions, the use of force by the paramilitary and police firings. New Delhi has treated insurgency in frontier states as a law and order problem, and has dealt with it by the 'deployment of military and para military forces, the suspension of the democratic process, and imposition of president's rule' (Dutt, 2006, 88).The removal of Farooq Abdullah's elected government in 1984, and the rigged elections of 1987, led the people of Kashmir 'to embark upon a full-fledged campaign aimed at severance of the Indian connection' (Bose and Jalal, 1998, 226). The central government at New Delhi did not keep its promises, and turned its back on holding the plebiscite that had been initially agreed. The Indian side argued that a plebiscite supervised by the international community dominated by the U.S. would not be fair, since Pakistan at this time was aligned with the western world through the SEATO/South East Asia Treaty Organisation. As far as the internal side of the conflict is concerned, it is also worth mentioning that, 'Indira Gandhi, for personal gain dangerously introduced the communal card into Kashmiri politics at a time when a new generation of Muslim Kashmiri's were more politically aware than ever before' (Talbot, 2000, 274). Puri writes, 'for fear of the secessionist challenge in the valley, India's policy makers denied the people of Kashmir free expression of their pride, their linguistic and cultural loyalty, their aspirations for a good and free life' (Puri in Weiner, 1968, 241).

The third war between India and Pakistan was a bit different in nature especially when compared with the earlier wars. The third Indo Pak war was started by India in the early seventies. In the previous two situations, Pakistan had initiated the war. The origins of this Indo Pak conflict were a lot more complex than the earlier ones. The origins are rooted in the exigencies of Pakistan's domestic politics, and because of the failure of the federative arrangement in Pakistan. Pakistan from 1947 till the year 1971 consisted of two Pakistan's, West Pakistan, which is today's Pakistan and former East Pakistan, which is today's Bangladesh. 'West Pakistan (present day Pakistan) was located on the western border of India, while East Pakistan (present day Bangladesh) was located on the eastern side of India' (Bhutto, 2008, 121). The Bengali speaking people of former East Pakistan were feeling very oppressed due to the misrule of West Pakistani politicians in their part of the country. For instance, the imposition of Urdu onto the Bengali speaking people caused considerable outrage, which led to the language riots (Ziring, 1992, 6). The language riots took place in the early fifties, shortly after the creation of Pakistan. Furthermore, the people of former East Pakistan had been subjected to both political and economic discrimination. The Bengali speaking people felt that they had been under represented in both political and military circles, and that their resources were being exploited to suit the needs of the then West Pakistan or the centre. Former East Pakistani's were involved in a struggle, trying to win political independence from West Pakistan. The nationalist leadership repeatedly blamed Pakistani rulers for exploiting and appropriating Bangladesh's 
resources and promised the people a very different kind of polity and politics once Pakistani colonial rule had been overthrown (Jahan, 2000, 26). Negotiations between the eastern and western sides of the country had reached a situation of political deadlock. Unable to break this situation of political deadlock, the then reigning military commander of West Pakistan who was entrusted with defending the country from internal and external threats alike, General Yayha Khan responded to the political aspirations of the Bengali leaders with tight repressive measures (Paul, 2014, 51). West Pakistan had also urged former East Pakistan to worship Mohammed Iqbal, who was a well-known West Pakistani poet and philosopher. Bengali poets and other intellectuals on the other hand were subjected to severe/harsh criticism.

For Bengali's, the Muslim League, which was the political party that had been hugely influential in the creation of Pakistan symbolised nothing but tyranny. Former East Pakistan felt under represented and West Pakistan never took competitive elections seriously. The Muslim League thought it could govern indefinitely, and treated all other national parties especially from the Bengali side with contempt. Confrontation replaced compromise. To West Pakistani politicians, any form of opposition threatened national unity, which would need to be crushed with a mighty hand. Thus, civil war began with the attack on the Bengali Awami League, whose leader, Sheikh Mujibar Rahamn was arrested, and many of the other prominent party leaders were killed or arrested. The Awami League grew in popularity amongst the Bengali speaking people, and tried to capture the government of former East Pakistan. The Awami League grew increasingly popular amongst the student community especially in the different universities, and this created fear in the hearts and minds of politicians from West Pakistan. The Awami League was proving to be too democratic and was threatening Pakistan's unity. Its demands to West Pakistan through the Six Point Program included the need to have a proper federation in the country, that the federal government should deal with the key defence issues, that there should be two freely convertible currencies, that the federated units should have the right to tax, that the federated units should have the right to be involved in free trade and finally that former East Pakistan should have its own militia (Ziring, 1992, 48). These demands were not acceptable to the West Pakistani establishment. To make matters worse, when a tidal wave hit former East Pakistan in the year 1970, there was an urgent need for assistance, to which West Pakistan turned a deaf ear and many of the politicians from West Pakistan proved to be unsympathetic. The political aspirations of the Bengali leaders grew stronger. West Pakistan used its army to crush the movement, and attacked Dhaka, especially Dhaka University and Chittagong. General Tikka Khan's targets included the East Bengal Regiment, East Pakistan Rifles, Border Guards and the Armed Police. These sections of former East Pakistani society in particular were seen as untrustworthy. Tikka Khan's campaign turned the survivors into the Bangladesh Liberation Force or the Mukti Bahini. Tikka Khan's goal was to get rid of the Awami League leaders, who were proving to be difficult and uncompromising. Mujib had been arrested and flown into West Pakistan. Bengali's were viewed with contempt by the West Pakistani politicians who saw them as quasi Hindus and also as anti-national. The Pakistani Army's message was that it would not tolerate any form of resistance and hence Pakistan through Yayha Khan responded with repressive measures to suppress the Bengali liberation struggle. In a span of three weeks, Pakistan's army strength in East Pakistan rose from 40, 000 to 70, 000 (Sengupta, 2011, 544). West Pakistan was not allowed to fly its troops over Indian air space, and hence troops from West Pakistan were shipped across the subcontinent which not only proved to be expensive, but also proved to be a long drawn protracted process (Ibid, 546). These repressive measures caused a huge human influx into Indian territory 
(Behuria in Dutt, 2012, 68).This huge inflow of Bengali people into India started to impact adversely on the Indian economy and, as far as Hindu nationalists were concerned, it was also undermining India's Hindu character, people from former East Pakistan being predominantly Muslim. At this stage, strategic thinkers at New Delhi took action. They thought it would be cheaper to go to war than to accommodate such huge numbers of Bengali speaking, predominantly Muslim people. India helped the Bengali leaders from former East Pakistan and in 1971, we see the successful secession of former East Pakistan and the ultimate creation of the independent country of Bangladesh. India has viewed its intervention in the conflict as one of humanitarian intervention, and one of giving a helping hand to former East Pakistan. However, many have argued that its real reason to intervene actually suited its own national interests with regard to hard core security/territorial issues. The creation of a new country on India's eastern front meant that India could now focus its entire strength, men and military energy on the western front to deal with Pakistan over the unresolved Kashmir issue. In other words, a fragmented Pakistan proved to be less of a threat to Indian security. India had always feared the strength of a united Pakistan and thus had allowed the Awami League leaders to form a government in exile on Indian soil (Bhutto, 2008, 122). Military action during the third Indo Pak war was mainly restricted to the eastern side of the subcontinent, and it had less to do with the actual Kashmir area. In Kashmir, India's main aim was to check Pakistan's policy of territorial expansion, and in destroying Pakistan's military hardware. 'Hundreds of thousands of Bengali's had been killed in the Pakistani military's futile campaign to prevent Bangladesh from gaining its independence, drawing global outrage' (Small, 2015, 10).

Before we move onto the Kargil conflict it is worth mentioning that Yahya Khan (during whose leadership the 1971 Bangladesh Liberation War had taken place) had received support from the Islamist party Jamat I Islami in his anti-Bengali agenda (Mukherjee, 2010, 340). The Jamat I Islami is a political party that was founded in undivided India by Maulana Mawdudi in 1941. Mawdudi's political-religious awareness was first aroused in South India, where the Muslim Nizam's power was beginning to fade just before India's independence in 1947, and it seemed that political power was now beginning to shift to the dominant Hindu community in India (Nasr, 1994, 4). Aggressive antiMuslim campaigns spearheaded by Hindu revivalists had also started to take place at this time. In this connection, mention maybe made of the activities of the Hindu Mahasabha, the Arya Samaj and the Shuddhi campaign. Their activities made the Muslim community feel insecure in India, and many worried about what would be the future of Islam in post-independence India after the British had left. The Jamat I Islami Bangladesh and the Jamat I Islami Pakistan are offshoots of the original Jamat I Islami that was founded in India by Mawdudi (Karlekar, 2005, 139). Some of the current separatist leaders in Kashmir like Syed Geelani have strong links with the Jamat-I-Islami.

David Ludden writes, 'Kashmiri's fought to free Kashmir, erupting in the 1990's in pitched battles with the Indian Army, which produced a massive Indian military occupation of Kashmir and led to more upheavals and the alienation of Kashmiri identity from Indian nationality' (Ludden, 2014, 236-237). 'Militancy in the valley rose to a crescendo during the years 1993-1995. There were 5,247 violent incidents in 1993, 5,829 in 1994 and 5,938 in 1995. These were, in fact, the highest figures recorded during the decade, 1990-99' (Singh, 2001, 196). More recently, Indo Pak relations over Kashmir got worse in 1999, when fighting between the two countries took place along the LoC/Line of Control. In the year, 1998, nuclear tests had been carried out in South Asia, which to some extent can be seen as the origins of tensions. The Kargil Operation, of 1999, 'was another in a series of failed attempts to resolve Indo-Pakistani disputes through force or diplomacy' (Lavoy, 2009/14, 15). 
Pakistan attempted to infiltrate its troops into Indian territory and battles were fought in Kargil, Dras and Batalik. The infiltration of the mujahideen from Afghanistan and other parts of the Muslim world, have changed the complexion of the conflict in Kashmir, according to Prakash Singh (Singh, 2001, 196). 'Gradually, Pakistan's involvement in Jammu and Kashmir assumed the proportions of a covert war' (Nanavatty, 2013, 38). 'The Pakistan military, and particularly the ISI/Inter-Services Intelligence Agency, created a network or organisations that could engage in jihad in the Indian part of Kashmir after being trained in camps located on the Pakistani side of the LoC/Line of Control. In the process, active use was also made of the groups that had acquired experience during the Soviet occupation of Afghanistan' (Yasmeen, 2003, 192).

Most of these wars, which have been fought over Kashmir, have lacked coordination and proper organisation. For instance, it is believed that former military ruler of Pakistan, Pervez Musharraf, had kept his successor as army chief, Ashfaq Parvez Kayani, in the dark while carrying out the Kargil operation in 1999 (Bhattacharya, 2015). The Indian side has also admitted that its response to Kargil had been 'sluggish because the colonels heading its combat units in the high glaciers had been overage' (Balaji, 2015) According to John. H.Gill, the Kargil War of 1999 falls into a grey area between low intensity conflict and full scale war (Gill in Lavoy, 2009/14, 92). Some have also referred to the situation as 'near war'.

Former President and military general of Pakistan, Pervez Musharraf writes, 'As a back up to understanding the Kargil conflict it needs to be stressed that Kargil was not a one-off operation, but the latest in a series of moves and counter moves at a tactical level by India and Pakistan along the Line of Control in the inaccessible, snowbound Northern Areas. India would capture a location where they felt that our presence was thin, and vice versa. This is how they managed to occupy Siachen. This is how the Kashmiri freedom fighting mujahideen occupied the Kargil heights that the Indian army had vacated for the winter' (Musharraf, 2008, 87).

Since 1989, militant groups in Kashmir have 'sustained a campaign of violence and civil unrest in support of their demands for an independent Kashmir or unification with Pakistan' (Prakash, 2000, 315). One often asks the question, why the sudden rise of political violence in the post nineties period in Kashmir? To this, it has often been argued by scholars that India's flourishing democracy has empowered previously marginalised groups like sections of the Muslim community in Kashmir, who are now becoming increasingly assertive in Indian politics. This situation is often called the 'paradox of Indian democracy'. Since 1947, India has made investments in the educational sector in Kashmir, and with the rise of educational institutions, we see the rise of awareness amongst the new middle class intelligentsia who are now better politically informed, more aware of their rights as Indian citizens, and now they have made their demands even stronger. Although India has made all these investments in the region, India continues to undermine the growth and running of free and fair elections. For instance, intimidation of voters, tampering with ballot boxes, exploitation of state/regional resources for the sake of people living in India proper, have only exacerbated the situation and galvanised Kashmiri people into further action. Whilst older generations would put up with India's disregard of its democratic institutions, the new younger generation are much more aware and politically active. The rise in violence is not just because of what some call the paradox of Indian democracy, but also because of Pakistan's active support of militancy in the Kashmir valley. As Victoria Schofield argues, 'Pakistan's support of militancy in the Valley of Kashmir throughout the 1990 's gave it the reputation it has been trying to shed ever since: that it was a state sponsor of 
terrorism' (Schofield, 2008, 85). Despite denials, extremist groups based in Pakistan were quite obviously operating in Kashmir.

According to some statistical figures, as of 1995, 400, 000 Indian army troops and para military were deployed in the region of Jammu and Kashmir against the Pakistani and the Chinese armies, although many of these Indian troops got drawn into assisting the BSF/Border Security Force and the CRPF/Central Reserve Police Force in counter insurgency operations. In addition to the Border Security Force and the Central Reserve Police Force, another section of the Indian para military that has been active in Kashmir, are the Rashtriya Rifles. It is difficult to make an assessment of the number of insurgents involved in the situation, although some estimates suggest that the various insurgent groups combined would amount to 6000-8000 active combatants, of which 10002000 could possibly be Islamists infiltrating from the Af-Pak/Afghanistan-Pakistan region (Mukherjee, 2013, 94). It is believed that Pakistan's ISI/Inter-Services Intelligence has played a crucial role in operationalizing the infiltration of Islamists into Kashmir and India (Kaplan, 2011, 130). Pakistan has thus often used terror groups as a key part of its foreign policy, and has engaged India in low level intensity conflict since 1948 (Gupta, 2014, 144). Pakistan has opened fire against India as recently as January, 2015. It was reported in the Telegraph on the sixth of January, 2015, that 'Pakistani troops resumed firing on Indian positions today in Jammu after a day's lull, leaving a BSF/Border Security Force jawan dead and sparking an exodus of residents' (Special Correspondent, 2015). The same article continues to say, 'Davinder Kumar, hit by a shell in the Samba district, is the fourth BSF trooper to die over the past week in ceasefire violations blamed on Pakistan' (Ibid).

However, despite their common resistance to what is perceived as oppressive Indian rule in the region, the separatist elements are not united. They are highly fragmented in their approach. 'Complicating matters considerably are the divergent agendas amongst Kashmiri separatists, the various divisions within the state that preclude a consensus on its (post secession) future' (Webb, 2012,472 ). Some of these groups have more of an Islamic approach and some have a more secular approach. There are ideological and programmatic differences between the different groups. The Jammu and Kashmir Liberation Front is more of a pro-independence secular group whereas Islamist/pro Pakistan groups include Hizb-ul-Mujahideen, and the Harkat-al-Ansar. Azadi or independence from both India and Pakistan seems to be the sentiment of a lot of the people in the region. Of course for groups who want azadi need to think carefully about the consequences of independence. Independence could lead to severing connections with neighbouring India, which is likely to have hostile relations with Kashmir if Kashmir successfully seceded from the Indian union. This would prevent Kashmir from having access to the sea. All economies depend to some extent on maritime trade for their economies to flourish. So if Kashmir were to become independent, it would be a landlocked region with no access to the sea. In a post-independence/secession situation, the Kashmiri economy would have to face huge challenges to keep the economy alive and running. Any form of agricultural cultivation in the region is difficult because of the difficult mountainous terrain, so developing stronger economic linkages with India is necessary for its survival. India also has the responsibility of maintaining positive connections with its religious minorities and disadvantaged groups. The need of the hour is more dialogue with the Indian side rather than complete secession. 


\section{THE CURRENT SITUATION:}

Having travelled to the region recently myself, I was pleased to see a certain degree of normalcy and peace. ${ }^{1}$ The situation seemed much better in December, 2013, than in December, 2012 when I first visited Kashmir. When one arrives in Kashmir, one does not immediately get the impression that this is a conflict zone, although the presence of the military and para military forces can be quite disturbing. Outbreaks of violence can be erratic. The stories of ordinary people have always interested me, and thus when I visited the region in 2012/13, I made it a point to speak to the common people and see what information and data I could extract from the locals.

The first person I spoke to was a taxi driver who told me that the situation was now normal and that there was no real tension. ${ }^{2}$ The security personnel stationed in Kashmir tend to be men from India proper or the heartland region of India. When one travels from Srinagar Airport, to the Dal lake part of the city, which is the part of the city popular with tourists, one is surprised to see how heavily militarised the region is, although in Dec, 2013, the situation seemed better than what it had been in Dec, $2012 .^{3}$ The same taxi driver mentioned that the security personnel were just stationed there who did not have much to do, and that there was no real link between them being there and the actual conflict. In other words, the heavy presence of the military was not an indicator of the intensity of the conflict according to him.

The owner of a stationary shop told me that as a tourist it would be fine for me to roam around Kashmir freely and that there would be no problem ${ }^{4}$. The same person mentioned that if one travels from India till Jammu, one did not get to see the security forces, but it was only from Jammu onwards till the Kashmir valley, when people would get to see security personnel patrolling the streets. Like the first person, my second interviewee also mentioned that although one could see how heavily militarised Kashmir was, the presence of the security forces did not necessarily symbolise any on-going tension, and how grave the situation was. According to him, the main responsibilities lay with the state government, the central government and the media. He said to $m e$, if the government wants things to be fine, they will be fine and can even get better. ${ }^{5}$

Kashmiri shawls are world famous and I strolled into a traditional Kashmiri shop that sold beautiful handmade shawls. One of the owners of the shop mentioned something similar to what the earlier two men had said about the political situation, and that there was no tension, and that there was nothing to be worried about ${ }^{6}$. Another shawl owner, by the name of Amin, who was quite an old man also went onto say that there was no real political tension, but when there was any tension in Kashmir, it was actually caused by the BSF/Border Security Forces from India proper who are supposed to maintain peace ${ }^{7}$.

\footnotetext{
${ }^{1}$ Participant Observation, Fieldtrip to Kashmir, Funded by the RIF/Research Incentivisation Fund, PPR, University of Lancaster, Dec, 2012, and Dec, 2013.

${ }^{2}$ First Interview carried out by the author, Srinagar, Kashmir, 18.12.2013.

${ }^{3}$ Participant Observation, Dec, 2012 and Dec, 2013.

${ }^{4}$ Second Interview carried out by the author, Srinagar, Kashmir, 18.12.2013.

${ }^{5}$ Ibid.

${ }^{6}$ Third Interview carried out by the author, Srinagar, Kashmir, 18.12.2013.

${ }^{7}$ Fourth Interview carried out by the author, Srinagar, Kashmir, 18.12.2013.
} 
Another shopkeeper, by the name of Sohail, told me that the actual tension took place in the more extreme remote border regions which were more than a hundred kilometres away from Srinagar(the capital city of Indian Kashmir), where Pakistani militants tried to cross the border. ${ }^{8}$ When asked about the presence of the security personnel in the heart of Srinagar, he mentioned that this was for the protection of high profile people associated with the government, and also for the protection of the government/administrative/official buildings that were present. According to him, the security forces were not managing a problem as such because there was no problem to manage. The media, he believed exaggerated the problem. ${ }^{9}$ He also mentioned that if one didn't see people leaving their houses after dark, it had nothing to do with the tensed situation, but was mainly because of the bitter cold winters. Another man I spoke to mentioned that since the year 2000 , the tension had actually stopped, and even when there was tension politically, tourists still visited the region. In other words, the political situation no matter how bad, has never really stopped tourists from visiting Kashmir ${ }^{10}$.

Kashmir is well known for its lovely Shikara boats on the Dal lake which are hugely popular with tourists from all over the world. The old man who took me around the Dal Lake was a very friendly chatty old man who also mentioned that the problem had calmed down, and that the militancy in the region had existed many years ago from the 1990's onwards, but from 2000, the situation had become quite calm. He, like one of the earlier interviewees, mentioned that if there was any degree of tension it was in the more extreme borderland parts of Kashmir which shared borders with China, Afghanistan and Pakistan ${ }^{11}$. He maintained that the security personnel had been stationed there to protect the people and the government. However, he went on to say that the regional government of Kashmir is under the force of the Indian government, which is corrupt. The Indian government is not only corrupt, but it uses force to extract taxes from the Kashmiri locals, without giving them anything in return. ${ }^{12} \mathrm{He}$ told me in great detail about the discrimination which his own son had been subjected to, when his son had gone to cities like Bangalore in India proper to look for employment. He faced discrimination despite the fact that he had all the necessary educational qualifications. Whilst he was rowing his shikara boat, we came across a military boat stationed in the middle of the Dal Lake in the typical Indian military style. This boat was a BSF/Border Security Force boat, which I gathered was used by the security personnel to keep an eye on what was happening on the Dal Lake. This seemed quite out of place. For the Indian government to have stationed a military boat in the middle of a lake popular with tourists to keep a watchful eye on the people, to me seemed unacceptable. The same interviewee told me that local Kashmiri's were heavily taxed to feed these security personnel, who tend to come from India proper. He mentioned that the government of India would need to find the BSF/Border Security Forces alternative employment, and would need to free the land of Kashmir from these military personnel. ${ }^{13}$ Through the course of the conversation, I gathered that although initially this interviewee of mine had told me that things were fine, gradually as he started to open up and release some of his frustrations about India's policies in Kashmir, it clearly showed me that his views towards India were actually

\footnotetext{
${ }^{8}$ Fifth Interview carried out by the author, 18.12.2013.

${ }^{9}$ Ibid.

${ }^{10}$ Sixth Interview carried out by the author, 18.12.2013.

${ }^{11}$ Seventh Interview carried out by the author, Srinagar, Kashmir, 18.12.2013.

${ }^{12}$ Ibid.

${ }^{13}$ Ibid.
} 
quite unfavourable. It is possible if I had spoken to the earlier men for a longer time, they would have also done the same, and opened up.

Another shopkeeper of a handicrafts shop told me that he found it really annoying when people from India proper thought of Kashmir as a 'disturbed area'. He mentioned that there was no rape, no robbery in Kashmir, something that is very common in India proper, so why classify Kashmir as a disturbed region ${ }^{14} \mathrm{He}$ told me that the reason why the media exaggerated the whole conflict situation in Kashmir is because hotel managers and tourist agencies in other hill stations of India like Shimla, Nainital and Mussourie, had bribed the media and told the media to project negative images of Kashmir intentionally so that they would get all the tourists and make all the money. ${ }^{15}$ In other words, he knew and was confident that if Kashmir's situation was projected by the media as positive and peaceful, then most Indian tourists would visit Kashmir and not the other hill stations since Kashmir was far more beautiful with its breath-taking views of the Himalayas. The same interviewee also mentioned that the Border Security Forces/BSF were getting 'double pay packages' and other incentives to be in 'disturbed areas' like Kashmir.

A shikarawala by the name of Ibrahim, maintained that he wanted independence from both India and Pakistan. He mentioned that the presence of the security personnel was not only bad for the local tourism industry of Kashmir, but it was having an adverse impact psychologically on their children, who are growing up in a land watching their country being continuously patrolled by heavily armed men in uniform. ${ }^{16}$ He mentioned that previously, the 'Lonely Planet' tourist guide had a detailed section on Kashmir which encouraged tourists and travellers to visit Kashmir, but now it had only two pages, due to the political turmoil which was a shame. ${ }^{17}$ The same interviewee mentioned that in very recent times, when a group of young Kashmiri men protested against the presence of the Indian army in Kashmir, the Indian army fired bullets at them. He went onto say, whilst the Kashmiri's threw stones at the Indian Army, and held a placard which said, 'Indian ArmyGo Back', the Indian armed forces fired bullets back at them. ${ }^{18}$ Although he seemed very upset with these incidents which had taken place recently, he mentioned that the current situation had gotten better especially when compared with earlier times, and that he was hoping that it would get better in the years to come.

A young taxi driver mentioned to me that whilst he felt no anger towards India proper, he felt hurt and disappointed when a recent movie by the name of 'I am', projected Kashmir and Kashmiri's in an unfavourable light. The director of the movie was a man from India proper. ${ }^{19}$ The same interviewee told me that the Kashmir police often took the law into their own hands.

When I asked a different taxi driver, why the region was so heavily militarised, he said that recent firings had taken place due to the infiltration of Pakistani militants who had come into Indian Kashmir through the villages. ${ }^{20}$ He mentioned that the militants from Pakistan do not come through

\footnotetext{
${ }^{14}$ Eighth Interview carried out by the author, Srinagar, Kashmir, 18.12.2013.

${ }^{15}$ Ibid.

${ }^{16}$ Ninth Interview carried out by the author, Srinagar, Kashmir, 18.12.2013.

${ }^{17}$ Ibid.

${ }^{18}$ Ibid.

${ }^{19}$ Tenth Interview carried out by the author, Sonmarg, Kashmir, 19.12.2013.

${ }^{20}$ Eleventh Interview carried out by the author, Pehelgam, Kashmir, 20.12.2013.
} 
the usual routes, but come through the villages, and are always disguised. ${ }^{21}$ This was the reason why there were so many military men stationed on the highway or on the main road close to where all the villages were located. When I pressed him further for more information, and asked how he knew that these so called militants were from Pakistan, he said that they did not have the identity cards which the local Kashmiri people had.

An old man, who was the owner of an art emporium, mentioned that he and his people clearly wanted independence from both India and Pakistan. ${ }^{22}$ He mentioned that Indians only killed Kashmiri's. 'The Indian government is not listening'. ${ }^{23}$ He told me that 'we throw stones at the Indian Army, and they fire bullets in return'. ${ }^{24} \mathrm{He}$ told me that the central government encouraged Hindus to leave the region because Muslims were supposedly going to kill Hindus, but anyone can see that all Hindu temples in Kashmir like the well-known Shankaracharya temple is still here, but many of the mosques have been demolished. ${ }^{25}$ Kashmiri leaders tell many of the shopkeepers here to go on strike for independence, but the central government is not listening and is too strong. ${ }^{26}$ 'Our generation could not do anything, but maybe the next generation will succeed in winning azadi/independence' ${ }^{27}$ He maintained that the problem with actual firing happened more at the borders and not so much in cities like Srinagar. The same interviewee also mentioned that there was no business in Kashmir, which is why they had to set up business outlets elsewhere in India. This was obviously adversely impacting on the local economy. When I asked him about the levels of violence, he stated that the violence lasted till about 1995/2000, but now the situation had calmed down considerably.

A shikara man mentioned that rice, chal, da'al, all come from India. He looked at me and said, what can Pakistan really give us? ${ }^{28}$ He mentioned that he had been a shikara man/boat man by profession all his life, and so were his father and grandfather. 'We live on the income that comes through tourism, and our tourists primarily come from India proper. Without the tourism industry, me and my family would not be able to survive. What can Pakistan give us? Pakistan hamloag ko, kya dega?'. ${ }^{29}$ He went on further to say, Kashmir had no factories. Not much manufacturing was going on here, so not much money could be earned through the local industries. 'It's tourism that keeps us alive, and our tourists come from Hindustan/India proper'. ${ }^{30}$

When I was on my way back to New Delhi from Srinagar, on the last day of my trip, I got the chance to speak to a man of Naga origin who currently works for the Indian armed forces. He is currently posted in Srinagar, which is the capital city of Indian Kashmir. He told me that the insurgencies both in Kashmir, and in other parts of India's borderland regions such as the Indian northeast, were still going on. ${ }^{31}$ The main difference between the two border regions, he

\footnotetext{
21 Ibid.

${ }^{22}$ Twelfth Interview carried out by the author, Srinagar, Kashmir, 20.12.2013.

${ }^{23}$ Ibid.

${ }^{24}$ Ibid.

${ }^{25}$ Ibid.

${ }^{26}$ Ibid.

${ }^{27}$ Ibid.

${ }^{28}$ Thirteenth Interview carried out by the author, Srinagar, Kashmir, 20.12.2013.

${ }^{29} \mathrm{Ibid}$

${ }^{30}$ Ibid.

${ }^{31}$ Fourteenth Interview carried out by the author, Srinagar Airport, Kashmir, 21.12.2013.
} 
mentioned, as in between Kashmir and India's north-eastern borders, was the involvement of external forces in Kashmir, mainly Pakistan, and the absence of such forces in India's remote northeast. Pakistani militants were continuously infiltrating Indian territory and were able to do so because the Indo-Pak border was 'a porous one'. 'Although, it is guarded and fenced, some parts of the borders are still porous and are very difficult to control' ${ }^{32}$ It was the role of the armed forces in India to prevent this infiltration from happening and to maintain law and order in the borderland regions. ${ }^{33}$ Furthermore, in addition to the problem associated with infiltration, Pakistan's leaders and diplomats have also routinely met with Hurriyat leaders before bilateral talks with India, and whilst New Delhi has never been comfortable with the implicit inclusion of Kashmiri leaders in what it considers a bilateral issue, it has allowed such meets to happen (Kasturi, 2015, 4).

The situation today is still fraught with uncertainty, and peril. There are regular reports associated with the on-going turmoil in Kashmir in Indian newspapers. 'A string of militant attacks today left three policeman dead in the valley, the strikes coming a day after chief minister Mufti Mohammed Sayed claimed Jammu and Kashmir was as peaceful as any other state in India' (Special Correspondent, 2015). Since the conflict has gone on for decades, it has now become quite difficult to identify the real actors associated with the mayhem. However, one thing is clear. 'The lack of discipline in the army has become a serious menace' (Kishwar, 1998, 292). Like most armies in the world, the Indian army has had a tendency to treat local people with contempt and this has strengthened the sense of marginalisation local Kashmiri's feel (Ibid, 290). The Indian Army has often misused and abused the Armed Forces Special Powers Act, which gives them extraordinary power to deal with the situation and supposedly manage the conflict. For instance, the army recently killed a youth in Tral, south Kashmir, whom the army saw as a militant, but local residents believe to be innocent (Raina, 2015). The death of the 24 year old youth, Khalid Muzaffar Wani triggered off protests, and hundreds took to the streets (Special Correspondent, 2015) In the context of the AFSPA, it is worth mentioning that Chief Minister, Mufti Mohammed Sayed has recently made a commitment to 'gradually lift the Armed Forces Special Powers Act from the state' (Special Correspondent, 2015).

Of course, the on-going violence is also caused by local militants, and Islamist groups. In a recent article, which came out in the Telegraph, it was said that the army had recovered a huge cache of arms and ammunition from slain militants, which included 'two AK-47 rifles and grenades, in addition to a floating water bag, two tiffin boxes and torches' (Special Correspondent, 2015). The easy access to weapons in Kashmir has problematized the situation. In a recent article, it was mentioned that a constable guarding the residence of senior PDP minister Syed Altaf Bukhari had fled with two automatic rifles (Briefs, 2015). The state government has recently put several leading separatist leaders, including Masarat Alam and Syed Ali Shah Geelani under house arrest, in order to prevent them from carrying out their separatist activities (Raina, 2015). An alliance of militant groups based in Pakistan occupied Kashmir has recently threatened to prevent any move to accommodate Kashmiri pandits (most of whom are Hindus) in a separatist homeland in the valley which has only served to exacerbate the situation (Special Correspondent, 2015). Separatist rallies with pro Pakistani leanings in Kashmir are still quite common today (Raina, 2015). For instance, the most prominent woman separatist in Kashmir, Asiya Andrabi is known for and has been accused of

\footnotetext{
${ }^{32} \mathrm{Ibid}$

${ }^{33}$ Ibid.
} 
unfurling the Pakistani flag in Kashmir. Recently, she was booked under the Unlawful Activities Prevention Act. Andrabi, who heads the Dukhtaran-i-Milat/daughters of faith separatist group, had 'been booked under Section 13 of the act, which could lead to a jail term of up to seven years' (Special Correspondent, 2015).

There is no doubt that this conflict has multiple layers and new conflicts often arise from earlier incidents. For instance, a new political storm has erupted in Jammu and Kashmir over the mortal remains of Afzal Guru, who was hanged recently by the Indian government on account of his participation in the Indian Parliament attack in 2001 (Special Correspondent, 2015). Search operations which add more fuel to the conflict is almost a regular occurrence in Kashmir. Recent incidents have occurred at places like 'Sultanpora village in Kashmir's Baramulla district where the police and army's Rashtriya Rifles and 176 Battalion had launched a cordon-and-search operation after learning about the presence of militants' (Special Correspondent, 2015). In this incident, the militants had fired on the search party.

India still receives death threats from Islamist groups, which have strong ties with Kashmir. 'New Delhi have been alerted about a possible suicide strike by the banned Jaish-e-Mohammed terror group after central security agencies recovered a note from a militant killed in the Samba attack in Jammu and Kashmir last month. The note said, 'we will meet in Delhi next' (The Telegraph, 2015). The recent events in Kashmir have made Indian officials take more of a tough stance to deal with the problem. For instance, the BJP has 'asked its deputy chief minister, Nirmal Singh, to 'talk tough' to chief minister Mufti Mohammed Sayeed if he 'persisted' in pursuing an agenda that went against the 'letter and spirit' of the government's common minimum programme' (Bureau, 2015). This happened after Sayeed's decision to release Hurriyat hardliner, Masarat Alam. The Union home ministry has also sought for a report from the Jammu and Kashmir government on the release of Alam (Dholabhai and Ramaseshan, 2015). India's tough stance succeeded to some extent when the Jammu and Kashmir government in less than 24 hours withdrew a circular that 'reaffirmed the equal sanctity of the state flag and the Tri-colour, apparently to placate the BJP' (Raina, 2015). Of course it is doubtful to what extent India will succeed in its current tough stance since the PDP-led government has been determined to free more separatists 'despite the country-wide uproar over the release of Masarat Alam' (Special Correspondent, 2015). The current incidents clearly show that the situation in Kashmir does not move in a straight line. Sometimes it might seem that the Kashmir regional government and the Indian government at New Delhi have made progress, but subsequent events might roll back the achievements in a very short span of time. The violence is sporadic and Kashmir's future still seems to be fraught with both peril and uncertainty.

Recently, in August, 2015, security agencies detained four Kashmiri separatist leaders, including Shabir Shah and Bilal Lone, after they reached Delhi to meet with Pakistan's national security adviser, Sartaj Aziz. Pakistan's high commissioner in New Delhi, Abdul Basit, had invited separatist leaders to a reception he was to host for Aziz, but the reception eventually had been called off (Bureau, 2015, 4). Every now and again Pakistani militants are being caught by security officials in India. A suspected Pakistani militant, Sajjad, alias Abu Ubaidullah, 22, was caught in Kashmir in late August, 2015, after a twenty hour gunfight in which four other militants were killed. Police sources said that the Pashto-speaking Sajjad was from Baluchistan, as were the other four (Special Correspondent, 2015, 7). Some sources have suggested that Sajjad was a Lashkar operative (Ibid). Army chief General Dalbir Singh Suhag recently mentioned that India must be prepared for 
'short wars' if Pakistan carried on supporting violence in Kashmir, and if this violence spread and intensified (Special Correspondent, 2015, 4). In recent years ceasefire violations have also gone up (The Telegraph, 2015, 5). 'Pakistani troops ratcheted up tensions on the border on a day a high level delegation from the country came to India for director-general level talks between the Indian BSF/Border Security Force and Pakistani Rangers' (Special Correspondent, 2015, 7). Pakistani officials said that their delegation, led by Major General Umar Farooq Burki, gave numerous examples of ceasefire violations allegedly by Indian troops along the Line of Control, which the two forces man. The BSF led by its director general, D.K.Pathak, objected to alleged infiltration bids by terrorists from Pakistan and cited the capturing of suspected Pakistani militant Mohammed Naved from the JammuSrinagar National Highway in Udhampur (Bureau, 2015, 6). The Telegraph recently reported of 'three bullet-ridden bodies', which had been recovered from a village orchard in Baramulla, which triggered off protests in the area. Two of slain individuals were identified by the police as militants of the Lashkar-e-Islam, a splinter group of the Islamist group Hizb-ul-Mujahideen (The Telegraph, 2015, 4). Again, there have been reports of five militants being killed as the army foiled an infiltration bid in north Kashmir's Gurez sector (Special Correspondent, 2015, 10). What is most tragic is that children have also lost their lives in the process (Special Correspondent, 2015, 4).The recent incident in Sopore testifies to this (Ibid).

The violence in Kashmir is on-going, and there are a new set of factors which have recently added to the tensed situation in Kashmir. In September, 2015, the Jammu and Kashmir High Court asked the state police chief to enforce a decades old ban on beef sale, which ultimately triggered a political 'row with several groups vowing to defy the ban publicly' (Special Correspondent, 2015, 7). Hurriyat's Syed Ali Shah Geelani has called for shut downs and demonstrations against the beef ban (Ibid). People slaughtered cattle in public across Kashmir as a protest against the Jammu and Kashmir High Court directive to the administration to enforce the longstanding but largely ignored ban on beef (Raina, 2015, 4). Many of these protestors got injured in the process. Some of them started to wave Pakistani flags and clashed with security forces who used tear gas and canes to break up the crowds of protesters. Many of the separatist leaders such as Geelani were placed under house arrest as a precaution. Several political and religious groups have argued that just as beef eating hurts the religious sentiments of Kashmir's minority Hindus, similarly the consumption of alcohol hurts the feelings of the majority Muslims in Kashmir (Raina, 2015, 4). The Karwan-e-Islami, a religious group that had in the past campaigned for a liquor ban, threatened to hit the streets to press its demand (Ibid). The National Conference party of Kashmir, which is now in opposition, plans to 'move a bill seeking an end to the state's beef-ban law' (Bureau, 2015, 5). Party leader, Rahim Rather said that the party would move the bill in early October. 'The National Conference is moving a bill seeking changes in the law that makes slaughter of a cow, ox or a buffalo a non-bail able offence with a jail term of ten years' (Special Correspondent, 2015,4). The National Conference in Jammu and Kashmir has moved a bill in the Assembly seeking to decriminalise slaughter of cows and the sale and consumption of beef in the state (The Telegraph, 2015, 6). Hindu nationalists like the Vishwa Hindu Parishad have threatened counter agitation in Kashmir over the subject of beef ban. VHP state president Leela Karan Sharma said in Jammu, 'If the beef ban law is revoked, the VHP will enforce an economic blockade with regards to Kashmir' (Special Correspondent, 2015, 10). The Jammu and Kashmir government had also suspended internet services for two days as several groups vowed to defy the beef ban with mass slaughter of bovines during Bakri Id (Special Correspondent, 2015, 5). The Jammu and Kashmir government also sacked two lawyers linked to the 
beef ban case, thereby apparently giving in to pressure from groups seeking their removal (The Telegraph, 2015, 4). Despite this, some senior minister's in the Jammu and Kashmir government vowed to continue eating beef. Sports minister, Imran Ansari, also a noted cleric, said in his individual capacity that there was no question of a ban on beef (Special Correspondent, 2015, 4). To add to the turmoil, a BJP MLA by the name of Ravinder Raina, has submitted an Assembly resolution seeking 'the death penalty for those involved in cow slaughter' (Ibid). Kashmir has been seething with rage since the court recently directed the state to enforce and implement the decades old law, which had been promulgated by the Dogra rulers banning beef in the state (Special Correspondent, 2015 , 4). But protests have continued. Afzal Qadri, a former Kashmir University law professor mentioned that the provisions banning beef went against the Indian constitution as well as that of Jammu and Kashmir. The Congress party in New Delhi has also expressed concern about the ban (Jha, 2015, 4).

\section{CONCLUDING REMARKS:}

From the above discussion, it is clear that the problem is still on-going, and it is difficult to make an assessment of the impact which the Kashmir conflict will have on regional Asian security. At this stage it is also difficult to make any future predictions, and as mentioned earlier the future is fraught with uncertainty. From the data that was gathered for this paper, some of the responses clearly show us that many are not happy with the way India has dealt with the situation in Kashmir over the years. And although, many told me that the situation had calmed down politically and that it was getting better, it is possible that these individuals did not want to reveal their true feelings to an unknown stranger. It is possible that they did not want to give out too much information on the politics of Kashmir to an unknown traveller. Some may have thought of me as a spy or a government servant, and this could have impacted on their responses to my questions. Maybe if I had the opportunity to spend a longer time with some of my interviewees, they would have revealed a much different story.

My seventh interviewee initially told me that things were okay, but when pressed for more information about the current situation, he revealed a different story. This was possible because I got the chance to have a longer conversation with him in a relaxed environment, when he was taking me around on the Dal Lake in his boat. The first few interviewees probably did not want to get into a detailed discussion with an unknown traveller about the politics of Kashmir. It is clear from some of the responses that some sections of the population want azadi or freedom from both India and Pakistan, although these sections would need to think very carefully about the quality of independence and the consequences of independence, and what might happen to Kashmir in a post secession/post-independence situation. Many of these individuals, who view India proper unfavourably, are quite old men who may have lived through the political turmoil of the sixties, seventies, eighties and nineties, when the situation was really bad politically, and it is possible that this has left an indelible mark on them.

The younger generation although more aware of their rights are also very individualistic in their ways and are influenced by global forces, which makes them want to move outwards into India proper to better themselves economically and to raise their material standards. The communitarian spirit may have weakened as globalisation has taken place. As they move outwards to establish new business outlets in India proper, this is likely to undermine the secessionist movement in Kashmir. 
Many from the younger generations seem to be more concerned about their individual careers and would like to make money in the 'new India', in the new urban centres, where there is a rising middle class with high purchasing power. It could be that many of these younger people are not so much concerned about the situation as their parents and grandparents were. That said, the younger generation have been active with the new social media in recent times, and have been regularly using Facebook to report incidents of violence especially committed by the Indian Armed Forces in Kashmir.

It was of course good to see, judging from some of the initial responses and through my own observations, that the situation had reached a certain degree of normalcy. That said, New Delhi has still a long way to go if it wants to win the hearts and minds of these people who have been oppressed for decades. India's undemocratic treatment of the Kashmiri people is like a black mark on India's democracy. Kashmir has been recognised as one of the most militarised parts of the world (Ahmed, 2013, 295), so a massive demilitarisation would need to take place to give people breathing space so that they can think and live in normal/human ways. Furthermore, the security personnel need to be more respectful towards the local people. As mentioned earlier the Indian Army has misused its power in Kashmir and treated people with contempt. The Armed Forces Special Powers Act which gives them extraordinary powers to deal with the situation needs to be removed. If the political elite at New Delhi feel that this cannot be done because of constant Pakistani infiltration from across the border, then at least there needs to be more accountability. The armed forces would need to be accountable to a higher authority. They should not be allowed to take the law into their own hands. If their actions are checked, then this can at least correct some of the problems in Kashmir especially as far as the internal dimension of the conflict is concerned. With regards to the external side of the conflict, talks would need to be held with Pakistan. Political transparency will in turn lead to more confidence building. More communication and dialogue with Pakistan is the way forward to deal with the external dimension of the conflict. The Indian government would also need to look into Kashmiri matters more urgently if it wants Kashmiri's to feel a sense of solidarity with India. In recent years devastating floods have caused absolute havoc in Kashmir, and the centre has not shown much sympathy during such times of crises. Many Kashmiri's have complained that they waited for months for the government to help, but this assistance did not come (special correspondent, 2015, 4).

The human rights situation needs urgent attention. Kashmir is well known for its human rights abuses often caused by the Indian Army and the paramilitary forces. Police brutality, and the atrocities committed on the people of Kashmir by security forces have been well documented by international human rights organisations, as well as by Indian civil rights groups. This is something that I also gathered from my first trip to Kashmir in December, 2012. Despite the consistent human rights violations in Kashmir, Indian public opinion has 'remained largely silent on the issue' (Joseph, 2000,42 ). It is quite common to hear from the locals that the security forces often take the law into their own hands, and abuse their position of power. The Indian security establishment needs to stop looking at local Kashmiri's as the Indian 'other'. They need to be trusted with full citizenship rights like any other Indian. Kashmiri's should not be treated like a subject population under imperial rule. Better governance and administration, political transparency, free-fair elections, and infra-structure development are some of the areas that need urgent attention. New Delhi would also need to look into issues associated with corruption, poverty and unemployment. Kashmiri's would need to be 
given a place in the decision making process. Hopefully, these things taken collectively will bring about effective and long lasting peace for the people of Kashmir.

\section{References:}

Ahmed, A., 2013, The Thistle and the Drone: How America's War on Terror became a Global War on Tribal Islam, New Delhi: Harper Collins Publishers.

Armstrong, K., 2000, A Short History of Islam, London: Phoenix Press.

Bajpai, K., 2002, Roots of Terrorism, New Delhi: Penguin Books.

Balaji, R., 2015, 'Kargil Blame on Overage Colonels', The Telegraph, Calcutta, 26.03.2015.

'Beef bill', 2015, The Telegraph, Calcutta, 18.09.2015.

Bhattacharya, A., 2015, 'Kargil's Shroud of Truth and Lies', The Telegraph, Calcutta, 14.03.2015.

Bhutto, B., 2008, Reconciliation: Her Last Words on Islam, Democracy and the West, London: Pocket Books.

Bose, S., and Jalal, A., 1998, Modern South Asia: History, Culture, Political Economy, New Delhi: Oxford University Press.

Briefs, 2015, 'Minister Guard', The Telegraph, Calcutta, 29.03.2015.

Brown, M.E., 1996, The International Dimensions of Internal Conflict, Cambridge, Massachusetts: MIT Press.

Bureau, 2015, 'Shah signals Mufti tough-talk', The Telegraph, 11.03.2015.

Bureau, 2015, 'Sushma springs metaphor to say parleys with Pak must start when time is right', The Telegraph, Calcutta, 23.08.2015.

Bureau, 2015, 'BSF, Pakistan Rangers trade charges', The Telegraph, Calcutta, 11.09.2015.

Bureau, 2015, 'Bill against beef law in Jammu and Kashmir', The Telegraph, Calcutta, 15.09.2015.

Burnham, P., Gilland, K., Grant, W., and Layton-Henry, Z., 2004, Research Methods in Politics, Basingstoke: Palgrave, Macmillian.

'Delhi Terror Alert', The Telegraph, Calcutta, 06.04.2015.

Dholabhai, N., and Ramaseshan, R., 2015, 'Delhi seeks Alam Report', The Telegraph, Calcutta, 09.03.2015.

Durward, R., and Marsden, L., 2009, Religion, Conflict and Military Intervention, Surrey: Ashgate.

Dutt, S., 2006, India in a Globalised World, Manchester: Manchester University Press.

Dutt, S., and Bansal, A., eds, 2012, South Asian Security: $21^{\text {st }}$ Century Discourses, London/New York: Routledge. 
Forsey, M.G., 2010, 'Ethnography as Participant Listening', Ethnography 11, no.4, pp558-572.

Frankfort-Nachmias, C., and Nachmias, D., 1992, Research Methods in Social Sciences, New York: St.Martins Press.

Guha, R., ed., 2014, Makers of Modern Asia, London/ Cambridge, Massachusetts: Belknap Press of Harvard University Press.

Gupta, S., 2014,The Himalayan Faceoff: Chinese Assertion and the Indian Riposte, Gurgaon: Hachette Publishing.

Habibullah, W., 2011, My Kashmir: The Dying of the Light, New Delhi: Penguin Books.

Hiro, D., 2011, Jihad on Two Fronts: South Asia's Unfolding Drama, New Delhi: Harper Collins.

Jahan, R., ed, 2000, Bangladesh: Promise and Performance, London/New York: Zed Books.

Jha, S.K., 2015, 'Congress lashes out at 'ban and fatwa' culture', The Telegraph, Calcutta, 17.09.2015.

Joseph, T., 2000, 'Kashmir, Human Rights and the Indian Press', Contemporary South Asia9, no1, pp41-55.

Kaplan, R.D., 2011, Monsoon: The Indian Ocean and the Future of American Power, New York: Random House.

Karlekar, H., 2005., Bangladesh: The New Afghanistan? New Delhi: Sage.

Kasturi, C.S., 2015, 'Hurriyat hurdle but talks on so far', The Telegraph, Calcutta, 20.08.2015.

Khan, Y., 2007, The Great Partition: The Making of India and Pakistan, New Delhi: Penguin Books.

Kishwar, M., 1998, Religion at the Service of Nationalism and other essays, New Delhi: Oxford University Press.

Kulke, H., and Rothermund, D., 1986, A History of India, London/New York: Routledge.

Lavoy, P., ed, 2009/14, Asymmetric Warfare in South Asia: The Causes and Consequences of the Kargil Conflict, New Delhi: Cambridge University Press.

'Lawyers sacked', 2015, 'The Telegraph, Calcutta, 23.09.2015.

Lieven, A., 2012, Pakistan: A Hard Country, New Delhi: Penguin Books.

Ludden, D., 2014, India and South Asia: A Short History, London: Oneworld Publications.

Mukherjee, K., 2010, 'Islamic Revivalism and Politics in Contemporary Pakistan', Journal of Developing Societies26, no3, pp329-353.

Mukherjee, K., 2013, 'New Wars' in Contemporary South Asia? Peace Review: A Journal of Social Justice25, no1, pp89-96. 
Mukherjee, K., 2014, 'The Kashmir Conflict in South Asia: Voices from Srinagar', Defence and Security Analysis30, no1, pp44-54.

Mukherjee, K., 2014, 'Comparing India's Disputed Borderlands: Kashmir and the Northeast', Jadavpur Journal of International Relations18, no1, pp31-62.

Musharraf, P., 2006/8., In the Line of Fire: A Memoir, London: Pocket Books.

Nanavatty, R.K., 2013, Internal Armed Conflict in India: Forging a Joint Civil Military Approach, New Delhi: Centre for Land Warfare Studies/Pentagon Press.

Nasr, S.R.V., 1994, The Vanguard of the Islamic Revolution: The Jamat-I-Islami of Pakistan, Los Angeles: University of California Press.

Paul, T.V., 2014, The Warrior State: Pakistan in the Contemporary World, Gurgaon: Random House.

Prakash, S., 2000, 'The Political Economy of Kashmir since 1947', Contemporary South Asia9, no3, pp315-337.

Raina, M., 2015, 'In Cuffs, Masarat Emerges Winner', The Telegraph, Calcutta, 18.04.2015.

Raina, M., 2015, 'Pak Cry at Hurriyat Show', The Telegraph, Calcutta, 16.04.2015.

Raina, M., 2015, 'Mufti Buckles in Flag Fight', The Telegraph, Calcutta, 14.03.2015.

Raina, M., 2015, 'Valley unites in street snub to beef ban', The Telegraph, Calcutta, 12.09.2015.

Raina, M., 2015, 'Tit for tat liquor ban call in Kashmir', The Telegraph, Calcutta, 13.09.2015.

Rashid, A., 2008, Descent into Chaos: Pakistan, Afghanistan and the Threat to Global Security, London: Penguin Books.

Scheibelhofer, E., 2008, 'Combining Narration-Based Interviews with Topical Interviews:

Methodological Reflections on Research Practices', Social Research Methodology 11, no5.

Schofield, V., 2010, Kashmir in Conflict: India, Pakistan and the Unending War, London: I.B.Taurus.

Schofield, V., 2008, 'Kashmiri Separatism and Pakistan in the Current Global Environment', Contemporary South Asia16, no1, pp83-92.

Sengupta, N., 2011, Land of Two Rivers: A History of Bengal from the Mahabharata to Mujib, New Delhi: Penguin Books.

Siddique, A., 2014, The Pushtuns: The Unresolved Key to the Future of Pakistan and Afghanistan, Gurgaon: Random House.

Singh, P., 2001, Kohima to Kashmir: On the Terrorist Trail, New Delhi: Rupa Publications.

Sinha, R., eds, 2012, Secular India: Politics of Minorityism, New Delhi: Vitasta Publishing.

Small, A., 2015, The China-Pakistan Axis: Asia's New Geopolitics, New York: Oxford University Press. 
Snedden, C., 2013, Kashmir: The Unwritten History, New Delhi: Harper Collins.

Special Correspondent, 2015, 'Pak Shells Kill Jawan, Tiger Exodus, The Telegraph, Calcutta, 06.01.2015.

Special Correspondent, 2015, 'Militants kill Three Cops in Valley', The Telegraph, Calcutta, 07.04.2015.

Special Correspondent, 2015, 'Valley Killing Protest', The Telegraph, Calcutta, 15.04.2015.

Special Correspondent, 2015, 'Mufti Vows to withdraw the Armed Forces Act', The Telegraph, Calcutta, 24.03.2015.

Special Correspondent, 2015, 'Second Jammu Raid in 2 days', The Telegraph, Calcutta, 22.03.2015.

Special Correspondent, 2015, 'Pak Day FIR on Valley Woman Separatist', The Telegraph, Calcutta, 26.03.2015.

Special Correspondent, 2015, 'Storm brews on Afzal Remains', The Telegraph, Calcutta, 12.03.2015.

Special Correspondent, 2015, 'Rebels Jump Cordon, Kill', The Telegraph, Calcutta, 03.04.2015.

Special Correspondent, 2015, 'Rebels Threaten to foil Pandit 'homeland' plan', The Telegraph, Calcutta, 10.04.2015.

Special Correspondent, 2015, 'Mufti's aide talks of more Masarats', The Telegraph, Calcutta, 10.03.2015.

Special Correspondent, 2015, 'Pakistani Militant', The Telegraph, Calcutta, 28.08.2015.

Special Correspondent, 2015, 'Army alert on short war', The Telegraph, Calcutta, 02.09.2015.

Special Correspondent, 2015, 'Border firing before meeting', The Telegraph, Calcutta, 10.09.2015.

Special Correspondent, 2015, 'Militants Killed', The Telegraph, Calcutta, 19.09.2015.

Special Correspondent, 2015, 'Child shooting shocks Kashmir', The Telegraph, Calcutta, 20.09.2015.

Special Correspondent, 2015, 'Beef ruling galls Kashmir', The Telegraph, Calcutta, 11.09.2015.

Special Correspondent, 2015, 'Beef ban stink in officer shift', The Telegraph, Calcutta, 16.09.2015.

Special Correspondent, 2015, 'Beef battle cry from VHP, valley clerics', The Telegraph, 19.09.2015.

Special Correspondent, 2015, 'Beef ban row' The Telegraph, 25.09.2015.

Special Correspondent, 2015, 'HC declines Bakri Id beef breather', The Telegraph, Calcutta, 22.09.2015.

Special Correspondent, 2015, 'Valley beef law challenged in court', The Telegraph, Calcutta, 17.09.2015.

Special Correspondent, 2015, 'After flood, tide of apathy', The Telegraph, Calcutta, 07.09.2015. 
Steele, J., 2011, Ghosts of Afghanistan: The Haunted Battleground, London: Portobello Books.

Talbot, I., and Singh, G., eds, 1999, Region and Partition: Bengal, Punjab and the Partition of the Subcontinent, Oxford: Oxford University Press.

Talbot, I., 2000, India and Pakistan: Inventing the Nation, London: Hodder Arnold.

Tharoor, S., 2012, Pax Indica: India and the World in the $21^{\text {st }}$ Century, Gurgaon: Penguin Books.

'Valley Bodies', 2015, The Telegraph, Calcutta, 15.09.2015.

Webb, M.J., 2012, 'Escaping History or Merely Re-writing it? The Significance of Kashmir's Accession to its Political Future', Contemporary South Asia20, no4, pp471-485.

Weiner, M., ed, 1968, State Politics in India, New Jersey: Princeton University Press.

Yasmeen, S., 2003, 'Pakistan's Kashmir Policy: Voices of Moderation?', Contemporary South Asia12, no2, pp187-202.

Ziring, L., 1992, Bangladesh: From Mujib to Ershad: An Interpretive Study, Dhaka: University Press Limited. 